\title{
ICHTHYOFAUNAL DIVERSITY AND PHYSICO- CHEMICAL FACTORS OF MELAMCHI RIVER, SINDHUPALCHOK, NEPAL
}

\section{Abha R. Mishra and Chitra Bahadur Baniya}

Journal of Institute of Science and Technology

Volume 21, Issue 1, August 2016

ISSN: 2469-9062 (print), 2467-9240(e)

Editors:

Prof. Dr. Kumar Sapkota

Prof. Dr. Armila Rajbhandari

Assoc. Prof. Dr. Gopi Chandra Kaphle

JIST, 21 (1), 10-18 (2016)

Published by:

Institute of Science and Technology

Tribhuvan University

Kirtipur, Kathmandu, Nepal

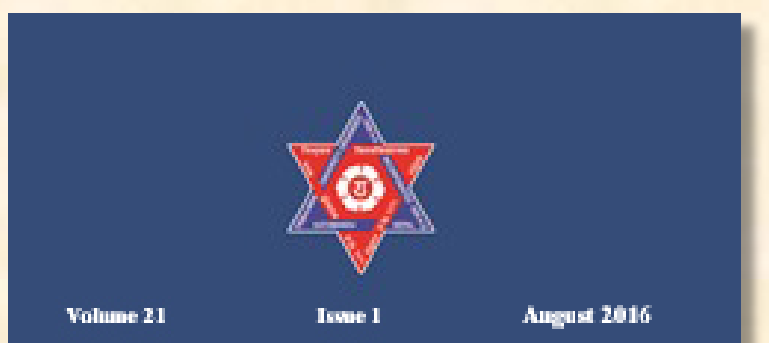

JOURNAL OF INSTITUTE OF SCIENCE AND TECHNOLOGY
Published by

Institute of Seience and Teehnology

Tribhuvan University
Kirtipur, Kathmanda, Nepal 


\title{
ICHTHYOFAUNAL DIVERSITY AND PHYSICO-CHEMICAL FACTORS OF MELAMCHI RIVER, SINDHUPALCHOK, NEPAL
}

\author{
Abha R.Mishra ${ }^{1, *}$ and Chitra Bahadur Baniya ${ }^{2}$ \\ ${ }^{1}$ Patan Multiple Campus, Tribhuvan University, Patan Dhoka, Kathmandu, Nepal \\ ${ }^{2}$ Central Department of Botany, Tribhuvan University, Kirtipur, Kathmandu, Nepal \\ "Corresponding email: mishraabha@hotmail.com
}

\begin{abstract}
The fish community and physico-chemical properties at five sites of Melamchi River was studied monthly from January 2011 to December 2013. Melamchi River is one of tributaries larger Indrawati River basin, originates from the high snowy Jugal Mountain $(5,875 \mathrm{~m}$ asl). Eleven fish species within two orders and five families were recorded. Cypriniformes was found to be the most dominant order with ten fish species. Schizothorax plagiostomus was the most common fish species followed by Neolissochilus hexagonolepis, and Psilorhynchus pseudecheneis. Shannon Wiener fish diversity index and species richness recorded were highest at site 2 and lowest at site 5, whereas, evenness index was highest at site 3 . The cluster analysis revealed that similarity between fish species decreased as the distance between the sites increased. Fish species were found distributed among four groups with respect to the significant habitat characteristics in the redundancy analysis (RDA). River water was found well-oxygenated and alkaline at all sites. However, high level for turbidity (43.25/ NTU) was observed at site 5, which exceeded compliance levels of WHO indicating the influence of intensive agriculture and deforestation along river area. To improve fish diversity and water quality of this river proper monitoring and management are an urgent need.
\end{abstract}

Keywords: Physico-chemical factors, Fish diversity, Cluster analysis, RDA

\section{INTRODUCTION}

The Melamchi Valley is the Himalayan RiverValley bestowed within mountain, forest, and agricultural landscapes. Melamchi River, a tributary of Indrawati River basin, originates from Jugal Himal, a high snowy mountain, located at an elevation of $5875 \mathrm{~m}$, central North Nepal. It flows southwards and joins Indrawati River near Pulbazar, Melamchi. During the course, the Melamchi receives around 50 tributaries, Timbu, Gohore, Gyalthum, and Talamarang are some of them. The river basin is used for irrigation, drinking water supply, recreation, micro-hydropower generation and water mills (EMP/MWSP 2009).

The healthy aquatic ecosystem is dependent on the physico-chemical and biological characteristics (Venkatesharaju et al. 2010). Among biological characteristics fishes are most important aquatic fauna serving as food, entertainment, biological control agents, animal feed, manure, decoration, sports, etc. Nepal is bestowed with a large number of rivers, considerable number of lakes, a few reservoirs, fishponds and irrigated fields. The indigenous and exotic fishes of Nepal total 217 species (Shrestha 2013). They are distributed from the lowland plains to the Himalayan Mountains. The three different categories of fish in Nepal are very cold-water fishes of Himalayan region, coldwater fishes of the middle region and warm water fishes of lowlands. There is a high demand for cold-water fish due to their excellent taste. It makes a significant contribution to the livelihood of the rural population of the Himalayan region. Rivers and streams are the best source of water not only for aquaculture but also for drinking purposes, power generation, irrigation and for domestic use. Therefore, biological monitoring of water bodies is also very necessary (Nikolsky 1963, Shrestha 1990, Allan 1995, Dudgeon 1999). Fish being an important protein resource for the poor country like Nepal, some aspects of the fisheries and fish ecological studies such as their diversity, spatial and temporal distribution and abundance in rivers as like the Melamchi are necessary.

\section{MATERIALS AND METHODS}

\section{Study area}

The Melamchi River (Fig. 1.), selected for this study has a total length of $41 \mathrm{~km}$. Its catchment is confined between $27^{\circ} 58^{\prime} 16^{\prime \prime} \mathrm{N}$ latitudes to 
$85^{\circ} 32^{\prime} 28^{\prime \prime}$ E longitudes. The Melamchi River flows southwards and joins the Indrawati River, near Melamchi pulbazar. The catchment at the Melamchi Pul Bazaar area encompasses area of 330 $\mathrm{km}^{2}$. In order to study and collect fishes, five confluence sites: Timbu, Gohore, Gyalthum, Talamarang, and Pulbazar (Fig. 1 and Table 1) were chosen.

\section{Fish sampling}

Fish samples were collected with the help of local fishermen in the first week of every month from
January 2011 to December 2013. Cast net of $6 \mathrm{~mm} \times$ $6 \mathrm{~mm}$ mesh size was used for the collection of fish samples. The time span for each site was between 50 to 60 minutes (with 15 hauls) as it was a factor to calculate the catch per unit effort (CPUE). CPUE in this work was defined as the number of fish captured in 10 minutes of hauling. Morphological characters of each fish sample were noted for the taxonomic confirmation. Fishes were categorized initially broadly with the help of local people, local fishermen and later scientifically by applying standard scientific methods of taxonomy (Jayaram 1999, Shrestha 1995).

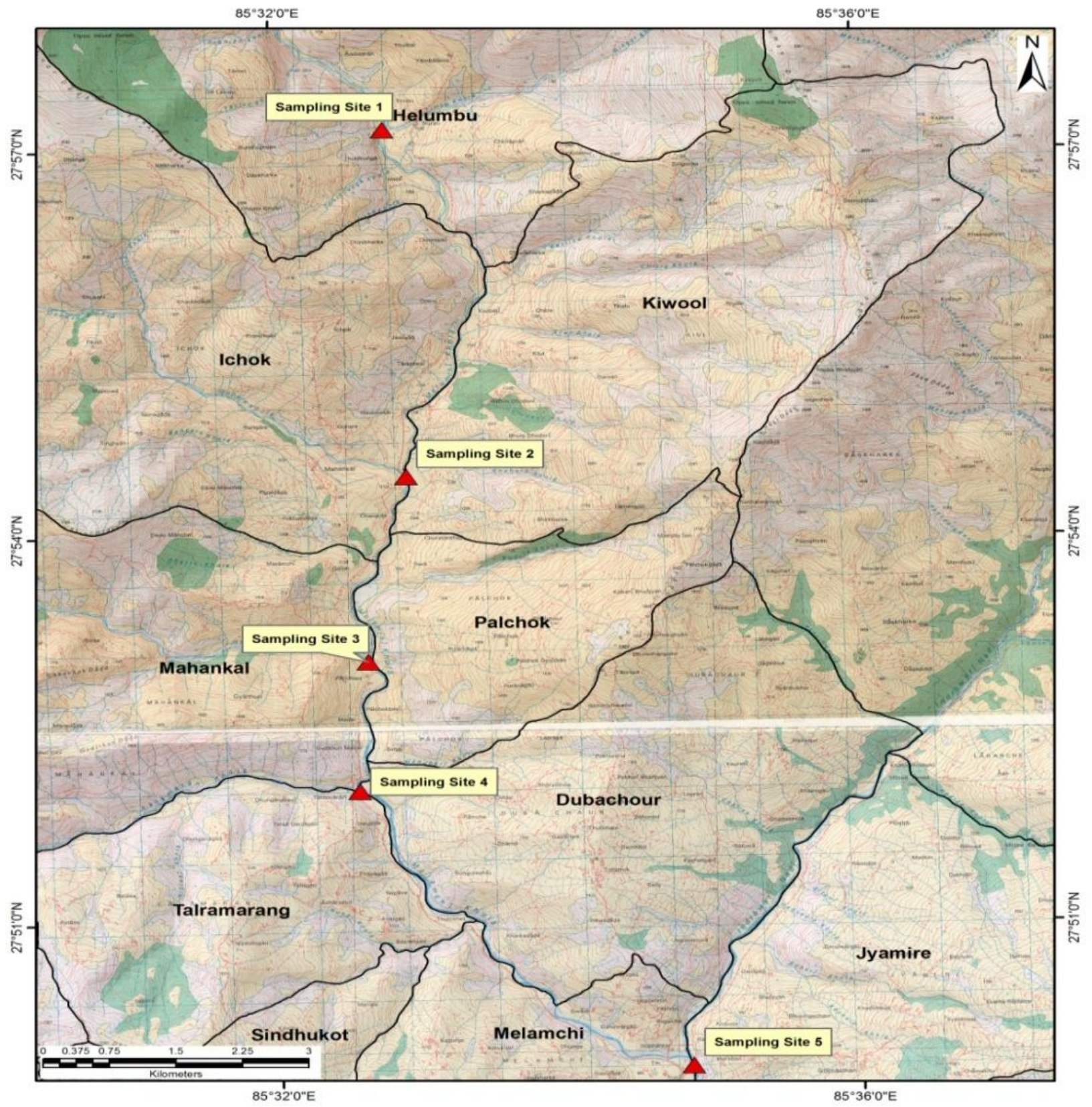

Fig.1. Map of the study area showing five sampling sites (with red triangle) 
Table 1. Species, number and percent composition of fish in Melamchi River from 2011-2013

\begin{tabular}{|c|c|c|c|c|c|}
\hline Order & Family & Genus & Species & \begin{tabular}{|c|} 
Total no. of \\
species in 3 yrs
\end{tabular} & $\begin{array}{l}\text { Species } \\
(\%)\end{array}$ \\
\hline \multirow{10}{*}{ 1. Cypriniformes } & \multirow{2}{*}{ Cobitidae } & Botia & Botia lohachata & 8 & 0.19 \\
\hline & & Lepidocephalus & $\begin{array}{l}\text { Lepidocephalus } \\
\text { guntea }\end{array}$ & 14 & 0.33 \\
\hline & \multirow{6}{*}{ Cyprinidae } & Barilius & Barilius barna & 28 & 0.66 \\
\hline & & Garra & Garra gotyla & 4 & 0.09 \\
\hline & & Neolissochilus & $\begin{array}{l}\text { Neolissochilus } \\
\text { hexagonolepis } \\
\end{array}$ & 166 & 3.9 \\
\hline & & Puntius & Puntius conchonius & 6 & 0.14 \\
\hline & & Schizothoraichthys & $\begin{array}{l}\text { Schizothoraichthys } \\
\text { progastus } \\
\end{array}$ & 134 & 3.15 \\
\hline & & Schizothorax & $\frac{\text { Schizothorax }}{\text { plagiostomus }}$ & 3722 & 87.53 \\
\hline & Psilorhynchidae & Psilorhynchus & $\begin{array}{l}\text { Psilorhynchus } \\
\text { pseudecheneis }\end{array}$ & 164 & 3.86 \\
\hline & Sisoridae & Pseudecheneis & $\begin{array}{l}\text { Pseudecheneis } \\
\text { sulcatus }\end{array}$ & 4 & 0.09 \\
\hline 2. Salmoniformes & Salmonidae & Onchorhynchus & $\begin{array}{l}\text { Oncorhynchus } \\
\text { mykiss }\end{array}$ & 2 & 0.05 \\
\hline
\end{tabular}

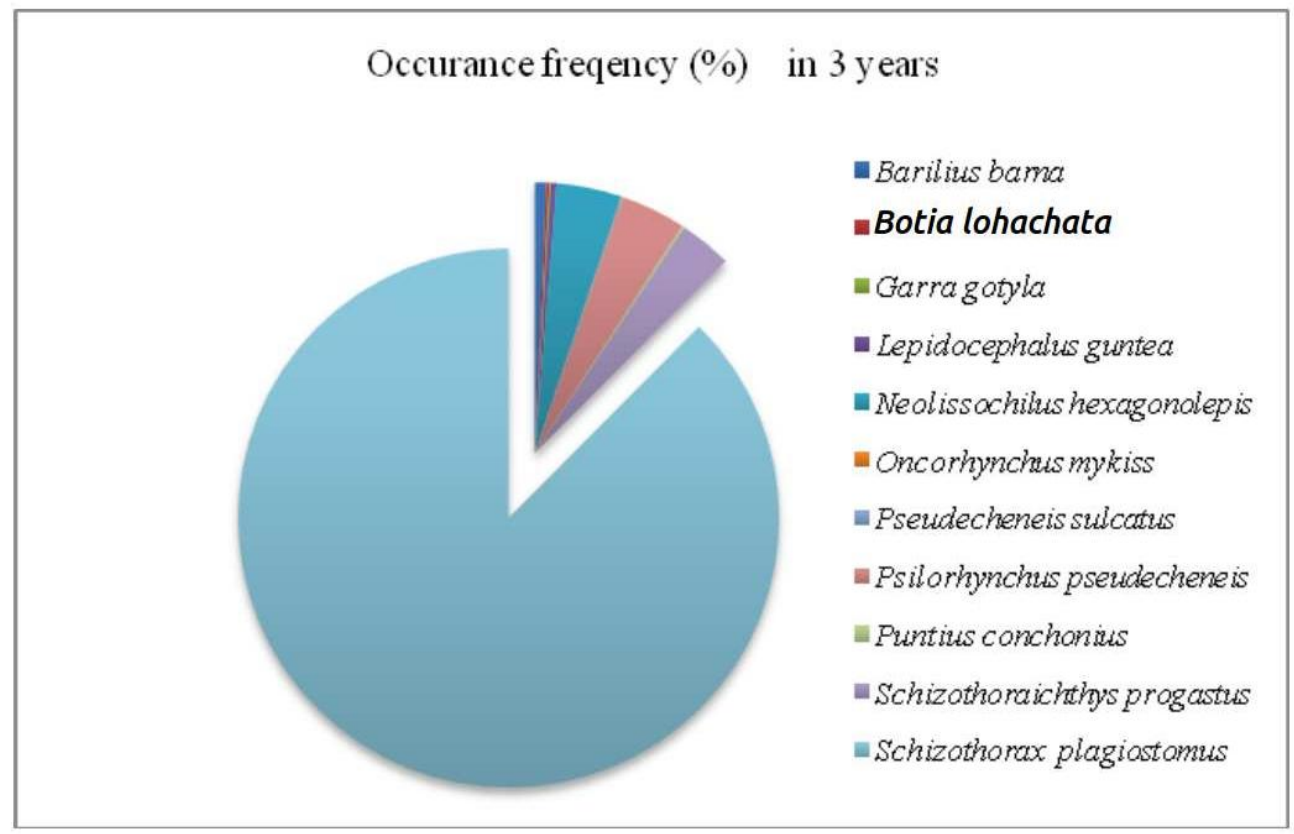

Fig.2. Fish species percent of Melamchi River from the year 2011-2013.

\section{Water sampling}

Water samples were collected in first week of every month from January 2011 to December 2013 in $1000 \mathrm{ml}$ clean PVC bottle from each site.
The collected samples were brought to the Melamchi Water Supply Project Laboratory, Melamchi. Analysis of various parameters of water was done within twenty-four hours of 
collection. Water temperature, electrical conductivity (EC, $\mu \mathrm{S} / \mathrm{cm}), \mathrm{pH}$, dissolved Oxygen (DO $\mathrm{mg} / \mathrm{l}$ ), total dissolved solids (TDS $\mathrm{mg} / \mathrm{l}$ ) and turbidity (NTU) were measured on the spot. Water temperature $\left({ }^{\circ} \mathrm{C}\right)$, was measured with the help of ordinary mercury thermometer by placing it inside the water at the depth of $1 \mathrm{ft}$. EC was measured by conductivity meter (Russell RL060C portable conductivity meter). Similarly, DO was measured by DO meter (Orion 3 star portable DO meter), TDS by conductivity meter (Orion 3 star portable conductivity meter), $\mathrm{pH}$ by $\mathrm{pH}$ meter (Orion 3 star portable $\mathrm{pH}$ meter) and turbidity by turbidity meter (Orion AQ3010) of Thermo Electron Corporation. Total alkalinity $(\mathrm{mg} / \mathrm{l})$ of water sample was determined by titrating it against standard acid solution using indicators such as phenolphthalein and methyl orange. Total hardness $(\mathrm{mg} / \mathrm{l})$ was determined by using EDTA titrametric method. $100 \mathrm{ml}$ of sample was titrated by $0.01 \mathrm{M}$ EDTA solution after the addition of indicator (very small amount of EBD + $1 \mathrm{ml}$ of ammonia buffer).

Calcium $(\mathrm{mg} / \mathrm{l})$ and magnesium $(\mathrm{mg} / \mathrm{l})$ content was determined by EDTA titrametric using $\mathrm{NaOH}$ solution and Murexide indicator. The chloride content $(\mathrm{mg} / \mathrm{l})$ of water sample was determined by titrating the water sample against $0.02 \mathrm{M}$ silver nitrate solution using potassium chromate as an indicator. Nitrate $(\mathrm{mg} / \mathrm{l})$ was determined by Brucine Absorbtivity method and phosphate $(\mathrm{mg} / \mathrm{l})$ by spectrophotometric method (APHA 2005).

\section{Data Analysis}

The entire observation period was divided into three fixed seasons: pre-monsoon (January, February, March, and April), monsoon (May, June July, and August), and post- monsoon (September, October, November and December). Only one sample (data) was taken every month. Four months data of each season were brought together to calculate seasonal mean values.

Site-wise Shannon-Wiener index, Simpson Index (D), Evenness index (J) and Species richness were calculated. In addition, these fish species were analyzed into different assemblage clusters as well as clustering of their sites based upon abundances of each fish species by utilizing pvclust package in R (Suzuki \& Shimodaira 2015). Similarly, fish community analysis was done though redundancy analysis (RDA) after utilizing vegan package in $\mathrm{R}$ (Oksanen et al. 2016).
All computations and graphics were achieved within the framework of $R$ (R Core Team 2016) to determine the mean, clustering and ordination.

\section{RESULTS AND DISCUSSION}

A total of 11 species of fishes under 2 orders, 5 family and 11 genera belonging to Cypriniformes and Salmoniformes order were captured during the entire sampling period at five confluence sites of Melamchi River of Sindhupalchok District, Nepal. Among 11 species of fishes, the family Cyprinidae was the most dominant in the assemblage followed by Cobitidae. During the investigation period, altogether 4252 fishes were captured. Schizothorax plagiostomus was the most dominant species present at all sites in all the seasons with $87.53 \%$ contribution of the total species followed by Neolissochilus hexagonolepis with $3.9 \%$ and Schizothoraichthys progastus was $3.15 \%$. Psilorhynchus pseudecheneis, Barilius barna, Botia lochata, Garra gotyla, Lepidocephalus guntea, Pseudecheneis sulcatus and Puntius conchonius species were less than $1 \%$. Oncorhynchus mykiss was recorded only once throughout the study period with lowest occurrence of $0.03 \%$ (Table 1, Fig.2). SMEC (1992) has reported 31 species from Melamchi and its tributaries. BPC (1996) has reported 43 species from Melamchi River. Sapkota (1998) reported 43 fish species from Melamchi River and 23 species between Yangri/Melamchi confluence downstream to Melamchi/ Indrawati confluence. EMP/MWSP (2009) reported 51 species from Melamchi River.

\section{Shannon-Wiener index}

The Shannon-Wiener fish diversity index of different sites ranged from 0.00 to 0.42 . In this study maximum fish diversity index was recorded in sites $2(0.42), 4(0.32)$ and $3(0.27)$ as compared to sites $1(0.18)$ and $5(0.00)$ (Table 2). Diversity was maximum in monsoon at all sites except site 1 , which showed highest diversity in pre-monsoon.

\section{Simpson Index (D)}

The Simpson diversity indexes in different sites varied from 0.00 to 0.22 (Table 2). It followed the pattern of Shanon-Wiener index. The highest diversity was recorded at site 2 and lowest at site 5 . Maximum diversity was recorded in monsoon at all sites except site 1 . This site showed highest diversity in pre-monsoon. 


\section{Species richness}

The species richness in five sampling sites showed considerable variation and higher richness was recorded in the mid regions. Maximum species richness was recorded in site 2 followed by sites 4 , while as lower species richness was recorded in site 1 and 3 and least in site 5 (Table 2). In midstream region, species diversity was high which might be due to the entrance of fish from tributaries. The less number of fish species in the lower region (site 5) may be due to high velocity of water, high temperature, turbidity and illegal fishing.

\section{Evenness Index ( $\mathbf{J})$}

Evenness is a measure of the relative abundance of the different species making up the richness of an area. The evenness index varied from 0.43 to 0.62 , the highest evenness was found at sampling site $3(0.62)$, while the lowest at site $5(0)$ (Table 2 ). The evenness index of site 1 and site 5 was lower than site 2 to site 4 . Middle regions of river were more diverse compared to upper and lower stretches.

Table 2. Diversity Indices of Melamchi River (Jan 2011-Dec 2013)

\begin{tabular}{|l|r|r|r|r|r|}
\hline \multirow{2}{*}{\multicolumn{1}{c|}{ Diversity Indices }} & \multicolumn{7}{|c|}{ Sampling Sites } \\
\cline { 2 - 6 } & \multicolumn{1}{c|}{ Site 1 } & \multicolumn{1}{c|}{ Site 2 } & \multicolumn{1}{c|}{ Site 3 } & \multicolumn{1}{c|}{ Site 4 } & \multicolumn{1}{c|}{ Site 5 } \\
\hline Shannon- Weiner index (H) & 0.18 & 0.42 & 0.27 & 0.32 & 0.00 \\
\hline Simpson index (D) & 0.10 & 0.22 & 0.15 & 0.18 & 0.00 \\
\hline Species richness & 1.67 & 2.44 & 1.78 & 2.00 & 1.00 \\
\hline Pielou's evenness (J) & 0.43 & 0.56 & 0.62 & 0.58 & 0 \\
\hline
\end{tabular}

\section{Cluster Analysis}

\section{pvCluster Analysis of fish species}

The pv Cluster Analysis of fish species (Fig. 3) generated a dendrogram with three main clusters or edge numbers. One of the main groups was ordinated at the left end of the plot with four clusters: $3,4,5$ and 8 . Within this group, three sub-groupings were observed; one in the centre of the plot (cluster number 3) was formed by $S$. plagiostomus and $N$. hexagonolepis species. This fish assemblage accounted for $96.8 \%$ of the individuals collected and $100 \% \mathrm{BP}$ value, the second sub group (cluster number 8 ) on the far left upper part of the plot was formed by two species, L. guntea, and P. conchonius, with $100 \%$ BP value. The third subgroup (cluster 5) formed in the middle of two subgroups also got $100 \% \mathrm{BP}$ value with first sub groups (3 and 4). Second group formed in the centre of plot (cluster number 2) with two species $P$. pseudecheneis and $S$. progastus with $100 \%$ BP value. Third group was formed by two subgroups at the right side of the plot. The first subgroup (cluster 1) was ordinated at lower part of plot with two species, B. barna and O. mykiss with $100 \% \mathrm{BP}$ value. Second sub group (cluster number 6) was formed significantly at the top right part of the plot with two species, G. gotyla and P. sulcatus, again having $100 \%$ BP. However, two subgroups of third group (cluster number 9) showed 99\% BP value. Four dominant species $S$. plagiostomus, $N$. hexagonolepis, $P$. pseudecheneis, and $S$. progastus occupied the central part of plot; the less abundant species $L$. guntea, P. conchonius and B. lohachata on the far left side; whereas least abundant species $B$. barna, O. mykiss, G. gotyla and P. sulcatus occupied the right side of plot.

\section{pvCluster Analysis of sampling sites}

Cluster analysis (CA) was also done to detect similarity among the five sampling sites and it showed strong spatial association (Fig. 4). CA generated a dendrogram grouping the similar sampling sites based on percentage of similarity and dissimilarity of fish assemblage. The analysis of bootstrapping probability value ranged $99 \%$ to $100 \%$ among significant clusters, indicating high correlation between sites as cluster. The pvclust confirmed that there was a significant cluster (cluster number 1) between site 1 (Intake/Timbu) and site 2 (Gohore), and cluster number 2 between site 3 (Gyalthum) and site 4 (Talamarang). Similarity between cluster 1 and 2 of four sites were $100 \%$ as by BP value. Contrary to these sites, site 5 was isolated and showed maximum dissimilarity with other sites during the entire study period, as it was located on the lower portion of the stream. The similarities decreased as the distance between sites increased. The impact of human activities at site 5 was also relatively high in comparison to other sites causing less fish assemblage. 
HIerarchial clustered dendrogram of fish species from the Melamchi River,

black and bold coloured number represents the cluster number, red represents probability of Automatic Unbiased $(A U)$ value and blue clolured number represents Bootstrap Probability (BP) value.

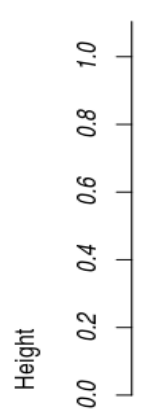

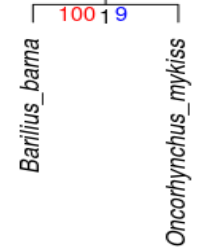
$\mathrm{AU}$ value $>$ or $=95$ represents significant cluster

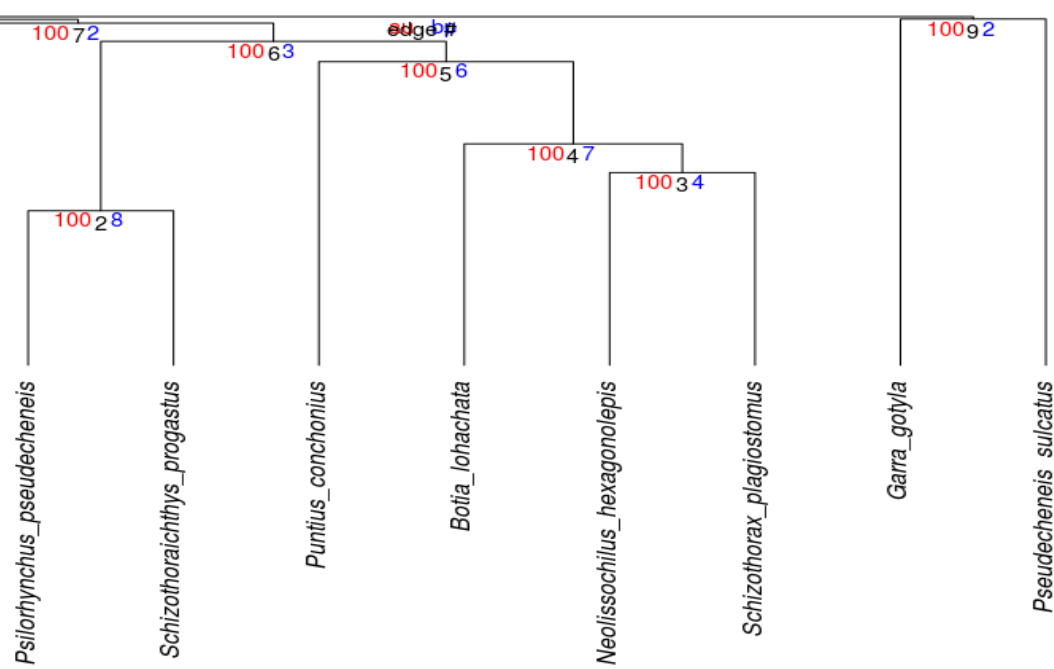

Distance: correlation Cluster method: average

Fig.3. Dendrogram of cluster analysis comparing fish species on the basis of fish assemblage.

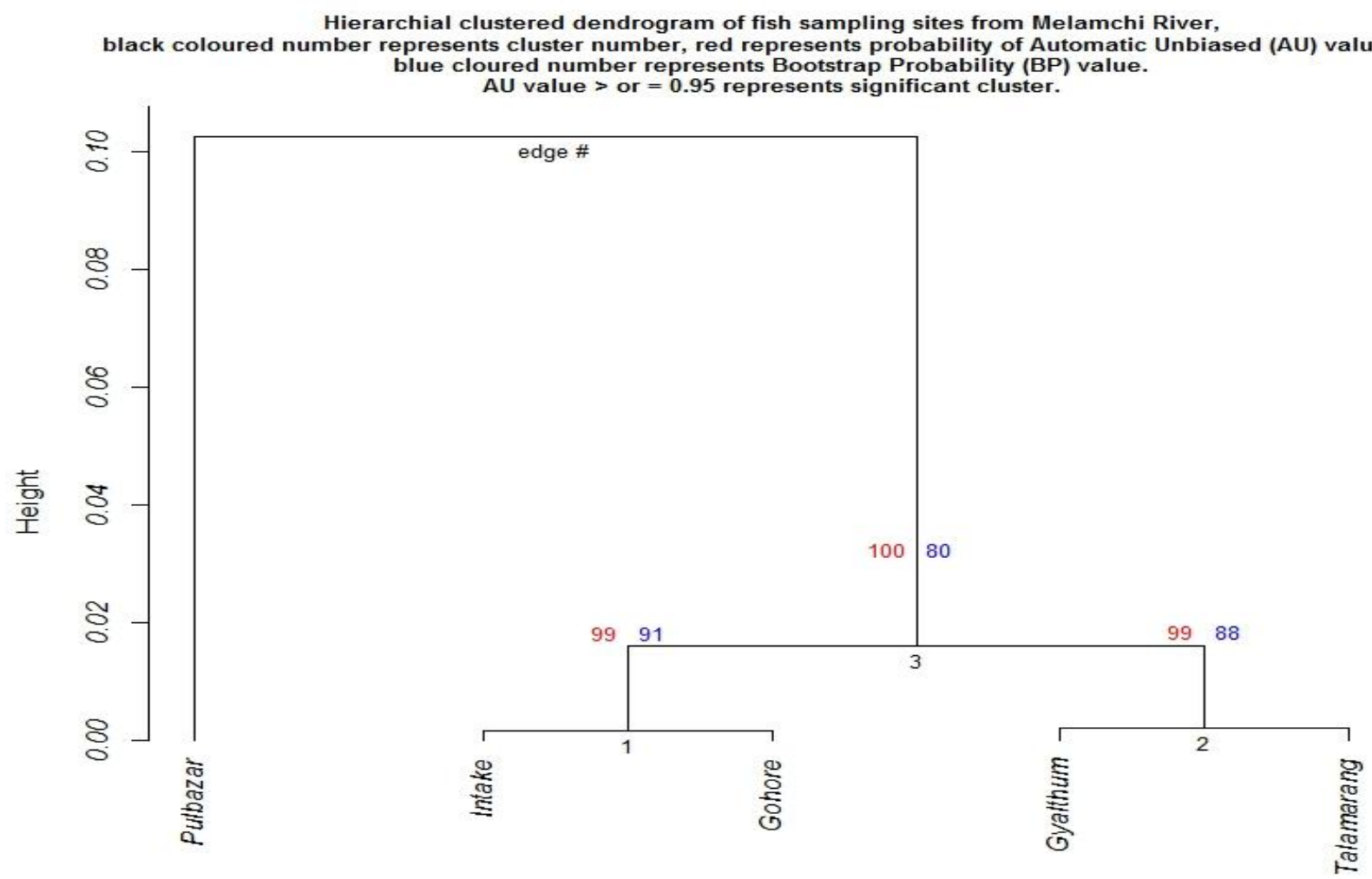

Distance: correlation

Cluster method: complete

Fig. 4. Dendrogram of cluster analysis comparing sampling sites on the basis of fish assemblage. 


\section{Seasonal variation in physico-chemical parameters}

Seasonal minimum average value of temperature (10.1 \pm 3.34$)$ was observed in pre-monsoon and reached at peak $(24.15 \pm 2.11)$ during monsoon (May-June) and then dropped suddenly in July/August, mainly due to rainfall and mixing of incoming cold water. Sharma et al. (2007) reported variation in temperature due to variation in altitude, which is characteristic feature of streams in the mid-hills with origin from the higher mountains. Seasonal maximum average conductivity was recorded in monsoon $(319.5 \mu \mathrm{S} / \mathrm{cm})$ and minimum in post-monsoon $(181.8 \mu \mathrm{S} / \mathrm{cm})$ at site 4 . In warm months, evaporation in water bodies decreases the total quantity of water causing increase in electrical conductivity (Hussain et al. 2013). During the study period, monsoon showed the maximum average turbidity (43.25) but the pre and post monsoon showed the minimum average turbidity (1.5 NTU). High value of turbidity in the monsoon season was found due to the agitation of water caused by rainfall (Garg et al. 2006). Silt, clay and other suspended particles contribute to the turbidity value in rainy season, while during winter and summer seasons settlement of silt, clay results low turbidity. Value of $\mathrm{pH}$ observed in the range of 7.28 to 9.22 , which indicated that water was alkaline in nature. Minimum average value of DO was $(6.42$ $\pm 0.04)$ in pre-monsoon and maximum (11.03 \pm 0.49 ) was recorded during monsoon. Low quantity of oxygen in summer can be attributed to the decreasing solubility level during increasing temperature and increasing decomposition ratio in warm days. The high DO in monsoon may be due to turbulence and oxygenation resulting from high rainfall and increased water flow. Alkalinity is important for fish and aquatic life because it protects or buffers against $\mathrm{pH}$ changes. Seasonal maximum average value of TDS was (203.61 $\pm 85.93)$ in pre-monsoon and minimum (111.37 \pm 17.21 ) in post-monsoon. Seasonal minimum average of total alkalinity was recorded in monsoon season $(24.68 \pm 4.42 \mathrm{mg} / \mathrm{l})$ and maximum average in post-monsoon $(58.21 \pm 21.5 \mathrm{mg} / \mathrm{l})$. Total Hardness also followed almost same pattern as total alkalinity. Hussain et al. (2013) also reported the same pattern of seasonal alkalinity. Maximum average value of Calcium content was recorded $9.37( \pm 3.39)$ in pre-monsoon and minimum (4.29 \pm 1.2 ) was in monsoon. Seasonal maximum average value of magnesium $(5.55 \pm 1.69)$ was observed in pre-monsoon and minimum average value $(0.54$ \pm 0.45 ) in monsoon. Low content of calcium and magnesium resulted into softness of Melamchi River, also supported by EMP/MWSP (2009). The seasonal maximum mean value of chloride $(26.47$ \pm 1.13 ) was observed in pre-monsoon and minimum mean value $(2.6 \pm 0.58)$ in monsoon. The highest concentration of calcium observed at all sites in pre-monsoon might be due to addition of domestic waste, sewage, and detergents through washing and bathing into the river. Natural sources of nitrate are animal debris, plant decay and igneous rock. The lowest seasonal mean value of nitrate $(0.35 \pm 0.3)$ recorded during monsoon and the highest seasonal mean value $(4.31 \pm 0.75)$ was recorded during postmonsoon. The lowest seasonal mean value of phosphate $(0.01 \mathrm{mg} / \mathrm{l})$ was recorded during monsoon at all sites and the highest seasonal mean value $(0.16 \pm 0.01)$ was recorded during postmonsoon. Accumulation of phosphate might be attributed to accumulation and addition through domestic discharge, sewage, and agricultural runoff where phosphate-containing fertilizers are used. In present analysis an increase in temperature, turbidity, chloride, phosphate and nitrate values was found, indicating mixing of organic waste load particularly sewage contamination and anthropogenic use. However, all the factors were within WHO (2011) permissible limit except turbidity.

\section{Environmental conditions and fish assemblage}

The RDA (Fig. 5) summarized the spatial trends in environmental gradients and species abundance. RDA Ordination plot was created for showing correlation among species assemblage with sites and physicochemical factors. Fish species were overlaid with sample points onto the RDA ordination plot. The vector lines radiated from the mean of all environmental variables. An angle and length of the line indicated the strength of that value. From the ordination plot, four main groups were identified. First group with the maximum abundance of two species $P$. pseudecheneis and $S$. progastus were significantly characterized by the highest value of calcium (Ca), and TDS. A second group, towards the negative end of RDA first axis, on the upper-left side of plot, corresponding to site 1 (Intake/Timbu) and site 2 (Gyalthum), comprised of the highest abundance of $S$. plagiostomus, $P$. sulcatus, B. lochata and B. barna. Their maximum assemblage was characterized significantly by the maximum value of water conductivity and temperature and the lowest value of turbidity, TDS 
and hardness (Thard). Especially, highest abundance of $S$. plagiostomus was significantly explained by the lowest value of water turbidity (Turb). Third group, towards positive end of RDA second axis, comprising of abundance of $N$. hexagonolepis and $P$. conchonius were significantly correlated with the highest value of temperature (Temp), pH, and conductivity (EC) and lowest value of water $\mathrm{Ca}$, TDS, and hardness. A fourth group towards the centre, near origin of both axis of RDA, significantly high abundance of $G$. gotyla and $L$. guntea were correlated with the high value of TDS, hardness and $\mathrm{Mg}$ and low temperature. Talamarang (Site 4) showed highly significant correlation with the highest value of the total hardness (T hard), TDS, and Mg, likewise Pulbazar (site 5) was characterized with high value of total phosphate.

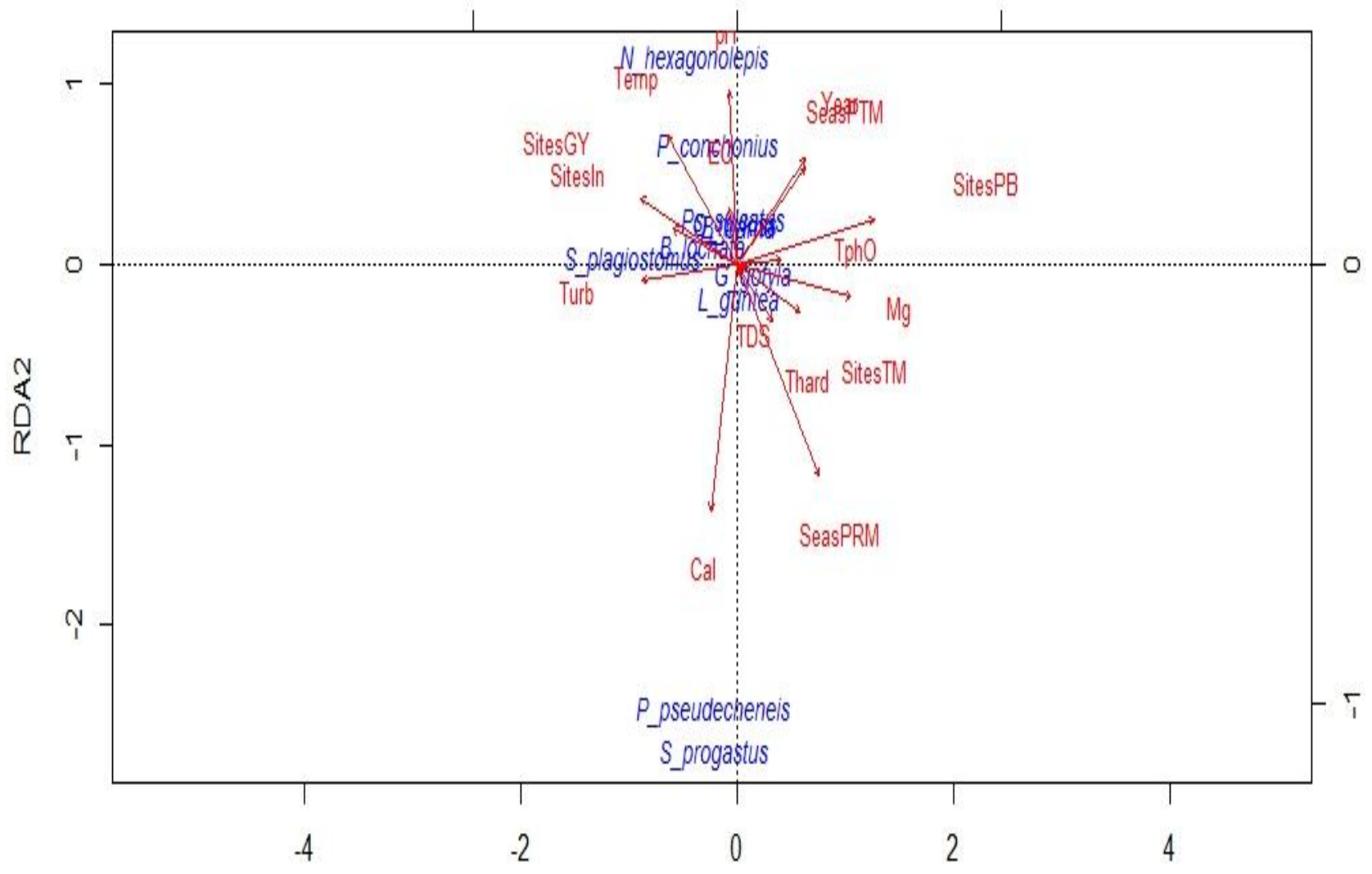

RDA1

Fig.5. RDA ordination plot created for sites, environmental factors, and species, based on seasonal average of all samples combined from Jan 2011 to Dec 2013, illustrating species distribution patterns based on environmental conditions and sites.

\section{CONCLUSION}

Present study concluded that there was a reduction in fish species number from 11 species to four species from 2011 to 2013. Species such as $N$. hexagonolepis, S. progastus and P. Pseudeheneis were the common fish species. Gyalthum (site 3) was found to be the fish species rich site but Timbu (Site 1) was the site with lesser numbers of fish species. Large scale illegal fishing was found in Pulbazar, nearby Melamchi area. Altitude, temperature and variability in water physicochemical character may be the cause of impact on fish species diversity.

\section{REFERENCES}

Allan, J. D. 1995. Stream ecology: Structure and function of running waters. Kluwer Academic Publishers, Dordrecht, the Netherlands pp. 388. 
APHA 2005. Standard methods for the examination of water and wastewater. 21st edition American Public Health Association, Washington, DC, USA.

BPC 1996. Technical Assistance to Melamchi Diversion scheme, Butwal Power Company (BPC) Final report, Vol 3.

Dudgeon, D. 1999. Tropical Asian streams: Zoobenthos, ecology and conservation. Hong Kong University Press, Aberdeen, Hong Kong pp. 830.

EMP/MWSP 2009. Status of fish, fisheries, and aquatic ecology of the Melamchi River. Environmental Management Program report, Melamchi Water Supply Project, EMP/ MWSP, Government of Nepal.

Garg, R. K., Saxena, D. N. and Rao, R. J. 2006. Assessment of physico-chemical water quality of Harsi Reservoir, district Gwalior, Madhya Pradesh. Journal of Ecophysiology and Occupational Health 6:33-40.

Hussain, A., Sulheria, A., Muhammad, Q. K., and Maqbool, A. 2013. Monthly variations in physicochemical parameters of a flood plain reservoir on River Ravi near Balloki Headworks (Pakistan), Biologia (Pakistan) 59 (2):371-377 PK ISSN 0006 - 3096.

Jayaram, K.C. 1999. The fresh water fishes of the Indian Region. Narendra Publishing house, New Delhi pp.1-322.

Nikolsky, G.V. 1963. The ecology of fishes. Academic Press, London pp. 352.

Oksanen, J., Guillaume Blanchet, F., Friendly, M., Kindt, R., Legendre, P., McGlinn, D., et al. 2016. Vegan: Community Ecology Package. R package version 2.4-0. https://CRAN.Rproject.org/package $=$ vegan .

$\mathrm{R}$ Core Team (2016). R: A language and environment for statistical computing. $\mathrm{R}$ Foundation for Statistical Computing, Vienna, Austria. URL https://www.Rproject.org/.
Suzuki, R. and Shimodaira, H. 2015. pvclust: Hierarchical Clustering with P-Values via Multiscale Bootstrap Resampling. R package version 2.0-0. https://CRAN.R-project.org/ package $=$ pvclust.

Sapkota, K. 1998. Fishes and fishing activity in The Melamchi River. Tribhuvan University Journal 21(1) 85-94.

Sharma, S., Banjade, S. and Bhandari, R. 2007. Impact of Khimti - I Hydropower Project in Nepal on the Ecological Status of River and Fishermen's Livelihood, International Conference on Small Hydropower - Hydro Sri Lanka, 22-24 October.

Shrestha, T. K. 1990. Resource ecology of the Himalayan waters. Curriculum Development Center, Tribhuvan University, Kathmandu pp. 645.

Shrestha, J. 1995. Enumeration of the Fishes of Nepal. HMG of Nepal/Governments of Netherlands, Biodiversity Profiles Project, Technical Paper No. 10, Kathmandu, Nepal.

Shrestha, J. 2013. Fish Biodiversity. In: Biological Diversity and Conservation, (eds) Jha, P. K., Neupane, F. P., Shrestha, M. L. and Khanal, I. P. Published by Nepal Academy of Science and Technology, Khumaltar, Lalitpur pp 69-81.

SMEC, 1992. Greater Kathmandu water supply project final report. Vol. 1 \&3. Snowy Mountains Engineering Corporation, (SMEC) Nepal.

Venkatesharaju, K., Ravikumar, P., Somashekar, R.K. and Prakash, K.L. 2010. Physicochemical and Bacteriological Investigation on the river Cauvery of Kollegal Stretch in Karnataka. Kathmandu University Journal of Science, Engineering and Technology $\mathbf{6}$ (1):50-59.

WHO 2011. Guidelines for Drinking Water Quality Vol. 1. Recommendations, World Health Organization (WHO), Geneva, Switzerland, $3^{\text {rd }}$ edition. 